NASA Technical Memorandum 105622

\title{
Evaluation of High Temperature Capacitor Dielectrics
}

Ahmad N. Hammoud

Sverdrup Technology, Inc.

Lewis Research Center Group

Brook Park, Ohio

and

Ira T. Myers

National Aeronautics and Space Administration

Lewis Research Center

Cleveland, Ohio

Prepared for the

Conference on Electrical Insulation and Dielectric Phenomena

sponsored by the Institute of Electrical and Electronics Engineers

Leesburg, Virginia, October 29-November 2, 1989

\section{N/SN}

(NASA-TM-105622) EVALUATION OF HIGH

TEMPERATURE CAPACTTOR OIELECTRICS (NASA)
$8 \mathrm{p}$

$8 \mathrm{p}$
CSCL $09 C$
N92-23551

Unclas

G3/33 0086836 


\section{EVALUATION OF HIGH TEMPERATURE CAPACITOR DIELECTRICS}

A. N. Hammoud

Sverdrup Technology, Inc. Lewis Research Center Group Brook Park, Ohio 44142
I. T. Myers

National Aeronautics and Space Administration Lewis Research Center Cleveland, 0hio 44135

\section{INTRODUCTION}

Dielectric materials find a wide spread use in many electrical systems and components such as high voltage capacitors, power cables, and electronic switching and sensing devices. In many applications, these components and devices have to operate in harsh environments where high temperature is encountered. Nuclear reactors, well-logging fields and space-based systems constitute, for example, such environments. The dielectric material, which is often the weakest element in any given electrical system, must, therefore, withstand high temperature exposure while still providing good electrical and other functional properties.

Today's technology of many advanced space power and electronic systems places a great emphasis on reducing the size and weight, increasing the packaging density, as well as improving performance and reliability. These requirements will certainly result in raising the operating temperature of the device concerned [1]. Improvement in the currently available dielectrics and the identification and development of new materials, capable of operating reliably at high temperature, thus play a crucial role for the requirements to be realized.

Four candidate materials were evaluated for use as high temperature capacitor dielectrics. The materials investigated were polybenzimidazole polymer and three aramid papers. The samples were characterized with and without heat treatment in terms of their dielectric constant and loss. These properties of the heat-treated samples were also evaluated in a temperature range of 20 to $250^{\circ} \mathrm{C}$ with an electrical stress of $60 \mathrm{~Hz}, 50 \mathrm{~V} / \mathrm{mil}$ present. While the $A C$ and $D C$ breakdown strengths of both dry and impregnated samples were determined at ambient conditions, the effect of heat treatment on these properties in the high temperature regime is currently underway. In this paper, the experimental procedures and the preliminary data obtained are reported.

\section{EXPERIMENTAL PROCEDURE}

The dielectric materials tested included polybenzimidazole - PBI (Hoechst Celanese), Voltex 450 (Lydall, Inc.), Nonex 410 and 418 (Du Pont). The thicknesses of these samples were $2,10,2$, and $3 \mathrm{mils}$, respectively. PBI is a linear thermoplastic polymer which has excellent thermal stability and strength retention over a wide range of temperature [2]. It is chemically stable and is used as 
reinforcement of high performance composites, filament winding and structural applications. Voltex 450, which is composed of aramid fiber and neoprene binder, has low water absorption and high dielectric strength [3]. It is commonly used as high temperature insulation in motors, generators and transformers. Nomex 410 and 418 are aramid papers made from synthetic aromatic polyamide polymer. They are chemically stable and radiation resistant and are cormonly employed as layer and barrier insulation in rotating machines and transformers. The 418 grade paper has $50 \%$ inorganic mica platelets and is designed for high voltage applications. The addition of the mica makes the properties of the insulation more stable with temperature [4]. Some properties of the materials tested are given in Table $1[2-4]$.

The experiments carried out on the candidate materials were performed on as-received (control C) as well as on heat-treated (HT) samples. Heat treatment was done by separately heating each material in an oven at a temperature of $60^{\circ} \mathrm{C}$ for a time duration of 4 hours. A capacitance measurement system (General Radio Precision Capacitance System 1621) together with a set of concentric ring brass electrodes were used in the measurement of the dielectric constant and the dissipation factor of the samples at room temperature in a frequency range of $50 \mathrm{~Hz}$ to $100 \mathrm{kHz}$. These properties were further characterized in a temperature range of 20 to $250^{\circ} \mathrm{C}$ with an applied electrical stress of $60 \mathrm{~Hz}, 50 \mathrm{~V} / \mathrm{mil}$ using Tettex Instruments, Type 2821 Capacitance System and Type 2914 Dielectric Test Cell.

A Hipotronics AC Dielectric Test Set (Model 7100-20A) and a Universal Voltronics DC power supply (Model BAM-32-1.5) were employed in the breakdown voltage measurements at room temperature. The breakdown strengths were obtained for dry (in air) as well as for samples impregnated with transformer oil. During testing, the specimen was held between two cylindrical stainless steel electrodes of 0.5 inch diameters and the voltage was raised at a rate of 500 $\mathrm{V} / \mathrm{s}$ until breakdown occurred. The values reported are the average of at least 7 measurements.

\section{RESULTS AND DISCUSSIONS}

The dielectric constant and the dissipation factor at room temperature of the materials as a function of frequency are shown in Figure 1. The data for the control samples are presented in the left column while those for the heat-treated ones are in the right column. It can be seen that while the dielectric constant of both Nomex papers did not experience any change upon heat treatment, it exhibited changes, with different degree and intensity, for the other two materials. That is, while that of Voltex 450 slightly increased, the dielectric constant of the PBI film decreased significantly. At any given frequency, this decrease amounted to about as much as $40 \%$ of the original value. Similar trend was observed for the effect of heat treatment on the dissipation factor 
property of all materials. Once again, the effect was more profound on the PBI film, as reflected by the sharp decrease in its loss. The dissipation factor of Nomex 418 al so decreased after the paper was heat-treated. It is believed that the reduction in the values of the dielectric properties after heat treatment is due to the removal of any moisture present and possibly to some thermallyinduced molecular agitation phenomenon.

Figure 2 shows the variation in the dielectric properties of the heat-treated samples as a function of temperature while electrically stressed at $60 \mathrm{~Hz}, 50 \mathrm{~V} / \mathrm{mil}$. It is evident that while the dielectric constant and the dissipation factor of both Nomex papers did not change with temperature, these properties of the other two materials increased appreciably at elevated temperatures. These changes occurred when the temperature reached $150^{\circ} \mathrm{C}$ for Voltex paper and $250^{\circ} \mathrm{C}$ for PBI film. It is important to note that while voltex started to char when the temperature exceeded $200^{\circ} \mathrm{C}$, the PBI polymer maintained its physical integrity at temperatures as high as $300^{\circ} \mathrm{C}$.

The $A C$ and $D C$ breakdown voltages of control and heat-treated samples are shown in Table II. Also listed are the data for dry as well as for transformer oil-impregnated samples excluding those of dry PBI film. Specimen needed to perform these measurements were not available. In general, the breakdown strength for the dry samples increased slightly after heat treatment. This might have been due to the removal of trapped moisture upon heating the materials. Table II also shows that the breakdown voltages of impregnated samples are much higher than their dry counterpart. This happens because the impregnant, which has higher dielectric strength than air, penetrates the material and fills up the microvoids and gas cavities as these are usually considered as primary sites for breakdown initiation.

\section{CONCLUSION}

The preliminary data indicate that heat treatment of the materials tested improves their dielectric properties and breakdown voltages. The $A C$ and $D C$ dielectric strengths are further improved upon impregnation with suitable liquid. Further experimental studies are required to better and fully characterize these and other materials for potential use as high temperature capacitor dielectrics.

\section{ACKNOWLEDGEMENTS}

The authors thank J. E. Ramirez and E. J. Powers (Hoechst Celanese), $J$. R. Messersmith (Lydall, Inc.), and P. E. Durchlaub (Du Pont) for suppiying the samples. Thanks are also due to the University of Buffalo for the use of their laboratory facllities. 


\section{REFERENCES}

[1] Sugimoto, E., "Applications of Polyimide Films to the Electrical and Electronic Industries in Japan," IEEE Electrical Insulation Magazine, Vol. 5, No. 1, 1989.

[2] Powers, E. J. and Serad, G. A., "History and Development of Polybenzimidazoles," in Hiah Performance Polvmers: Their oriain and Development, Seymour, R. B. and Krishenbaum, G. S., editors, Elsevier Pub., 1986.

[3] Lydall, Inc., Voltex 450 Product Bulletin, 9/88.

[4] Du Pont Co., Nomex Aramid Technical Bulletins E-91807 and E91809.

Table I. Properties of dielectrics tested [2-4].

\begin{tabular}{|c|c|c|c|c|}
\hline moFẹTY & 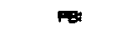 & VaTEX 450 & NONEX 410 & MONEX 418 \\
\hline $\begin{array}{l}\text { MAXMMM SERVICE TEMPERATURE }\left({ }^{\circ} \mathrm{C}\right) \\
\text { SHRIMAGE }(\mathbf{X})\end{array}$ & $\begin{array}{c}>300 \\
3 \div 3150\end{array}$ & $\stackrel{2200}{0.3 \bullet 1800 \mathrm{C}}$ & $\stackrel{2220}{1.6 \stackrel{300^{\circ} \mathrm{C}}{ }}$ & 0.4220 \\
\hline $\begin{array}{l}\text { DENSTY }(g / c . c) \\
\text { ELONGATION-AT-BAEAK }(\mathbf{X})\end{array}$ & $1.2-1.4$ & 16 & i1 & *.3 \\
\hline 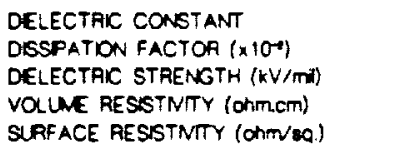 & $\begin{array}{c}4.4-162 \\
2.4=57 \\
4-7 \\
10^{44}-10^{4} \\
5 \times 10^{4}\end{array}$ & $\begin{array}{c}3.1 \\
1.61 \\
0.45 \\
*\end{array}$ & $\begin{array}{c}1.6 \\
0.4 \\
0.48 \\
10^{44}=10^{n} \\
10^{10}=10^{4}\end{array}$ & $\begin{array}{c}2.3-2.9 \\
0.6-13 \\
0.77 \\
10^{4}=10^{4} \\
10^{11}=10^{4}\end{array}$ \\
\hline
\end{tabular}

- onta currachele

Table II. $A C$ and $D C$ breakdown strengths.

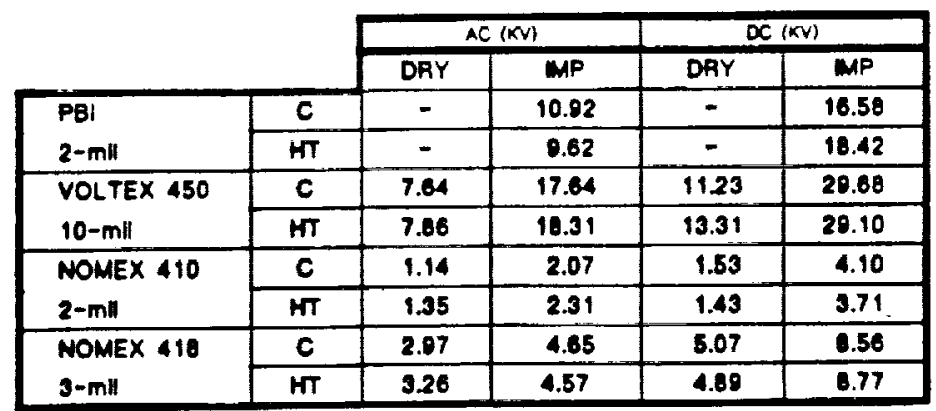

- TESTS WERE HOT PEFOOMED. C CONTRO: HT MEAT-TKEATED 

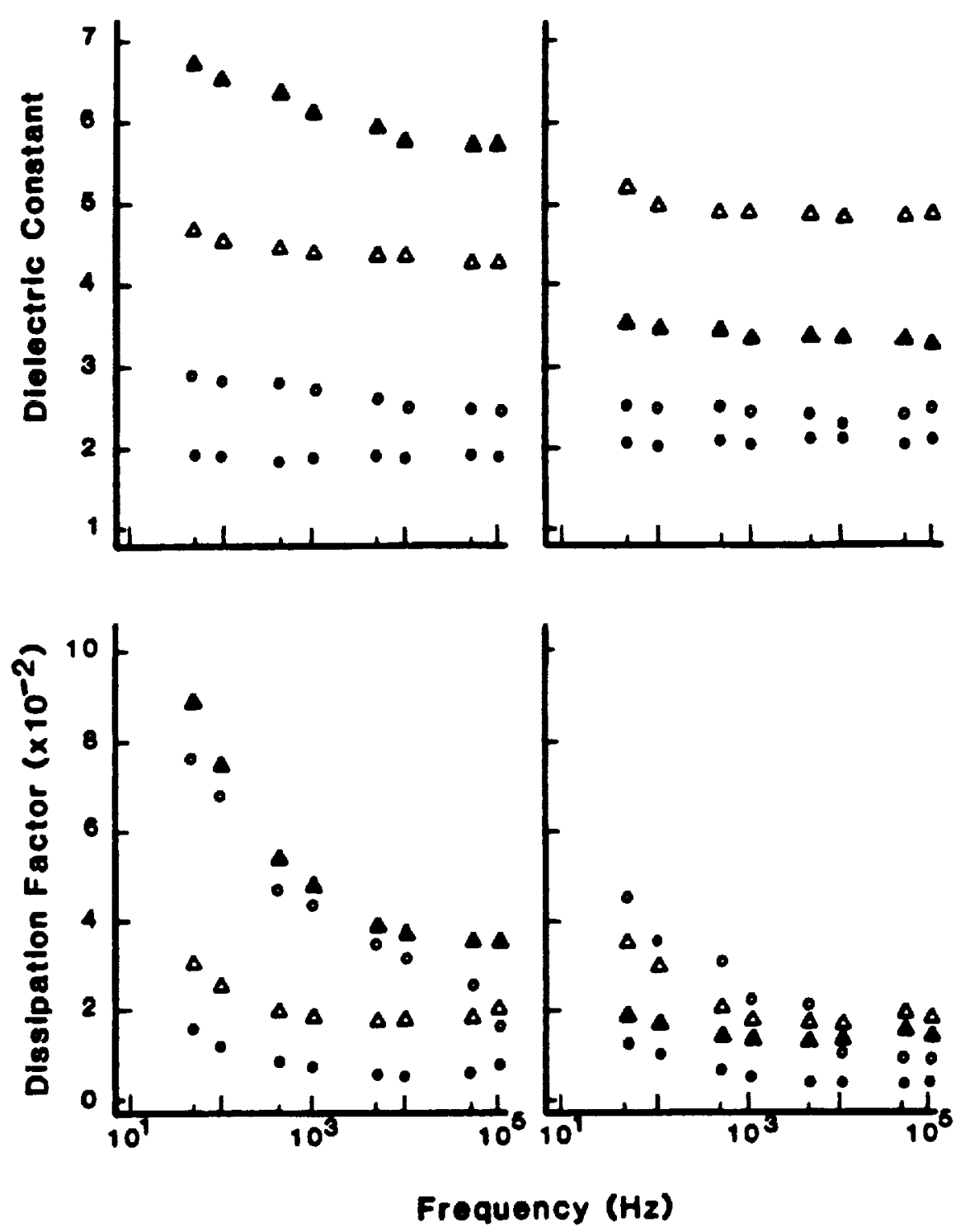

Figure 1. Dielectric properties vereus frequency for control (left column) and heat-treated (right column) samples. ( $\triangle$ : Voltex, $\triangle:$ PBI, $\bullet$ : Nomex 410, 0 : Nomex 418) 

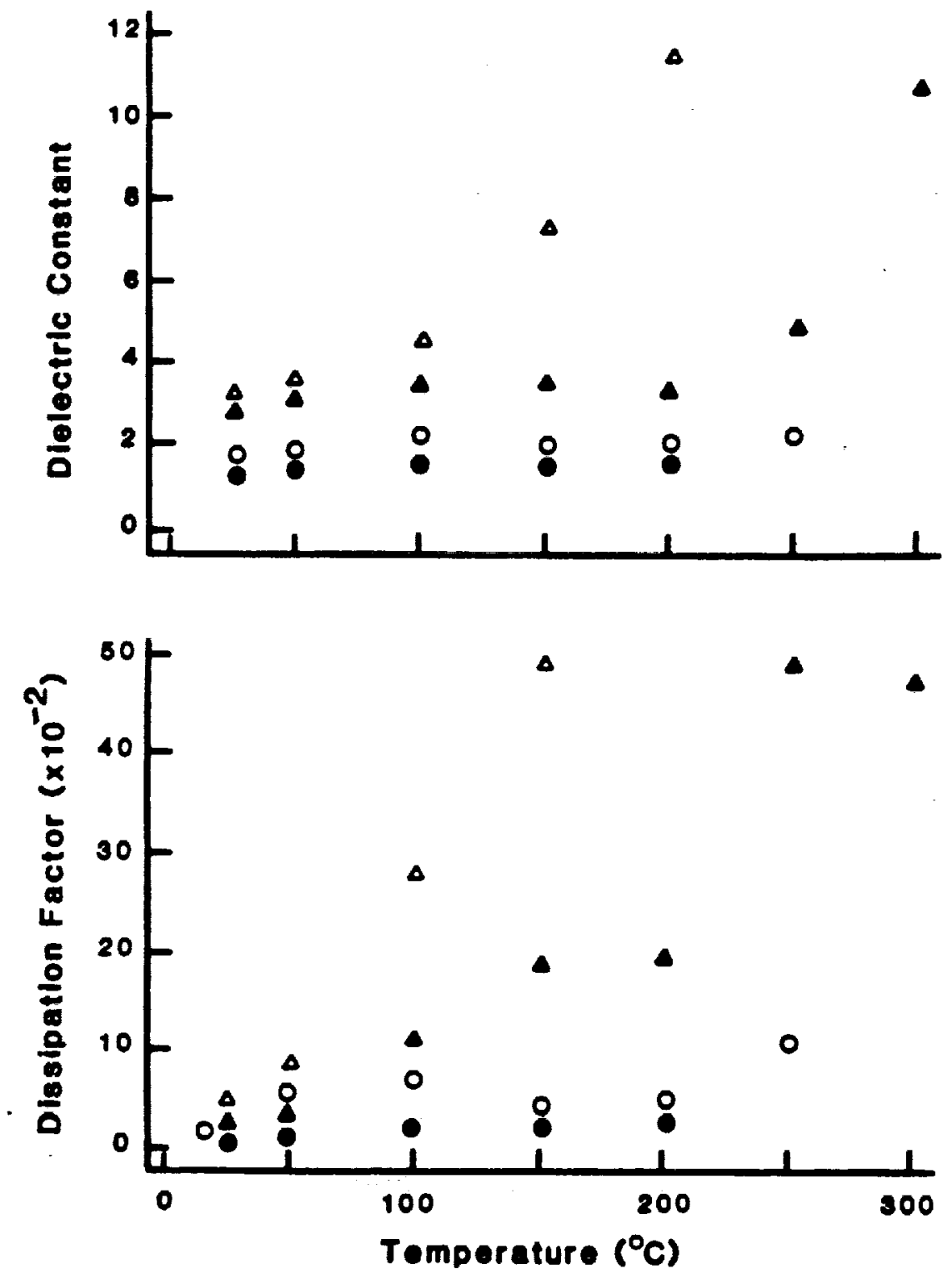

Figure 2. Dielectric properties of heat-treated samples versus temperature while electrically stressed at $60 \mathrm{~Hz}, 50 \mathrm{~V} / \mathrm{mil}$. ( $\triangle$ : Voltex, $\triangle$ : PBI, : Nomex 410, 0 : Nomex 418) 
Public reporting burden for this collection of information is estimated to average 1 hour per response, including the time for roviewing instructions, searching existing dala sources, gathering and maintaining the data needed, and completing and reviewing the collection of information. Send comments regarding this burden estimate or any other aspect of this collection of information, including sugnestions for reducing this burden, to Washington Headquarters Services, Directorate for information Operations and Feports, 1215 Jefferson Davis Highway, Suite 1204. Arlington, VA 22202-4302, and to the Office of Management and Budget, Paperwork Reduction Project (0704-0188), Washington, DC 20503.

\begin{tabular}{|l|c|c|}
\hline 1. AGENCY USE ONLY (Leave blank) & $\begin{array}{c}\text { 2. REPORT DATE } \\
1992\end{array}$ & $\begin{array}{r}\text { 3. REPORT TYPE AND DATES COVERED } \\
\text { Technical Memorandum }\end{array}$ \\
\hline 4. & $\begin{array}{r}\text { 5. FUNDING NUMBERS } \\
\hline\end{array}$
\end{tabular}

4. TITLE AND SUBTITLE

5. FUNDING NUMBERS

Evaluation of High Temperature Capacitor Dielectrics

Ahmad N. Hammoud and Ira T. Myers

WU-506-41-41

7. PERFORMING ORGANIZATION NAME(S) AND ADDRESS(ES)

8. PERFORMING ORGANIZATION REPORT NUMBER

National Acronautics and Space Administration

Lewis Research Center

$E-6960$

Cleveland, Ohio 44135-3191

9. SPONSORING/MONITORING AGENCY NAMES(S) AND ADDRESS(ES)

10. SPONSORING/MONITORING AGENCY REPORT NUMBER

National Acronautics and Space Administration

Washington, D.C. 20546-0001

NASA TM -105622

11. SUPPLEMENTARY NOTES

Prepared for the Conference on Elcctrical Insulation and Dielectric Phenomena sponsored by the Institute of Electrical and Elecironics Engincers, Lecsburg, Virginia, October 29-November 2, 1989. Ahmad N. Hammoud, Sverdrup Technology, Inc., Lewis Research Center Group, 2001 Acrospacc Parkway, Brook Park, Ohio 44142; Ira T. Mycrs, NASA Lewis Rescarch Center. Responsible person, Ahmad N. Ilammoud, (216) 433-8511.

12a. DISTRIBUTION/AVAILABILITY STATEMENT 12b. DISTRIBUTION CODE

Unclassified - Unlimited

Subject Category 33

\section{ABSTRACT (Maximum 200 words)}

Experiments were carried out to evaluate four candidatc materials for high temperature capacitor dielectric applications. The materials investigated were Polybenzimidazole polymer and three aramid papers: Voltex 450, Nomex 410 , and Nomex M 418, an aramid paper containing 50\% mica. The samples were heat-treated for 6 hours at $60{ }^{\circ} \mathrm{C}$ and the dc and $60 \mathrm{~Hz}$ ac breakdown voltages of both dry and impregnated samples were obtained in a temperature range of 20 to $250^{\circ} \mathrm{C}$. The samples were also characterized in terms of their dielectric constant, diclectric loss, and conductivity over this temperature range with an electrical stress of $60 \mathrm{~Hz}, 50 \mathrm{~V} / \mathrm{mil}$ present. Additional measurements are underway to determine the volume resistivity, thermal shrinkage and weight loss of the materials. Preliminary data indicate that heat-treatment of the films slightly improves the dielectric properties with no influence on their breakdown behavior. Impregnation of the samples leads to significant increase in both ac and dc breakdown strengths. The results are discussed and conclusions made concerning their suitability as high temperature capacitor dielectrics.

\begin{tabular}{|c|c|}
\hline 14. SUBJECT TERMS \\
Insulation; Dielectrics; Capacitors; High temperature
\end{tabular}

NSN 7540-01-280-5500

\begin{tabular}{|c|c|}
\hline & 15. NUMBER OF PAGES \\
\hline & 16. PAICE CODE \\
\hline $\begin{array}{l}\text { 19. SECURITY CLASSIFICATION } \\
\text { OF ABSTRACT } \\
\text { Unclassified }\end{array}$ & 20. LIMITATION OF ABSTRACT \\
\hline
\end{tabular}


